\title{
UPAYA KESEHATAN DAN KESELAMATAN KERJA DI RUMAH SAKIT DAN PENCEGAHAN PENYAKIT AKIBAT KERJA
}

\author{
FLORENCE ANGELINE NAINGGOLAN \\ Florenceangeline123@gmail.com
}

\section{Latar Belakang}

Menurut Undang-undang No. 44 Tahun 2009 Rumah Sakit adalah institusi pelayanan kesehatan bagi masyarakat dengan karakteristik tersendiri yang dipengaruhi oleh perkembangan ilmu pengetahuan kesehatan, kemajuan teknologi, dan kehidupan sosial ekonomi masyarakat yang harus tetap mampu meningkatkan pelayanan yang lebih bermutu dan terjangkau oleh

masyarakat agar terwujud derajat kesehatan yang setinggi-tingginya. Dari pengertian tersebut, rumah sakit melakukan beberapa jenis pelayanan diantaranya pelayanan medik, pelayanan penunjang medik, pelayanan perawatan, pelayanan rehabilitasi, pencegahan dan peningkatan kesehatan, sebagai tempat pendidikan, pelatihan medik dan para medik, sebagai tempat penelitian, pengembangan ilmu dan teknologi bidang kesehatan. Selain dituntut mempu memberikan pelayanan dan pengobatan yang bermutu, Rumah Sakit juga dituntut harus melaksanakan dan mengembangkan program Kesehatan dan Keselamatan Kerja di Rumah Sakit (K3RS) seperti yang tercantum dalam buku Standar Pelayanan Rumah Sakit dan terdapat dalam instrumen akreditasi Rumah Sakit.

Dalam Undang-Undang Nomor 36 Tahun 2009 tentang Kesehatan, Pasal 165 : pengelola tempat kerja wajib melakukan segala bentuk upaya kesehatan melalui upaya pencegahan, peningkatan, pengobatan, dan pemulihan bagi tenaga kerja. Berdasarkan pasal tersebut maka pengelola tempat kerja di Rumah Sakit mempunyai kewajiban untuk menyehatkan para tenaga kerjanya. Salah satunya adalah melalui upaya kesehatan kerja disamping keselamatan kerja. Rumah Sakit harus menjamin kesehatan dan keselamatan baik terhadap pasien, penyedia layanan atau pekerja maupun masyarakat sekitar dari berbagai potensi bahaya di Rumah Sakit. Oleh karena itu, Rumah Sakit dituntut untuk melaksanakan Upaya Kesehatan dan Keselamatan Kerja (K3) yang 
dilaksanakan secara terintegrasi dan menyeluruh sehingga risiko terjadinya Penyakit Akibat Kerja (PAK) dan Kecelakaan Akibat Kerja (KAK) di Rumah Sakit dapat dihindari. Penyakit akibat kerja di rumah sakit dapat menyerang semua tenaga kerja baik medis maupun non medis (Anies, 2005). Sehingga sasaran utama K3RS adalah tenaga medis, tenaga non medis, pasien, pengunjung / pengantar pasien, serta masyarakat sekitar Rumah Sakit.

\section{Metode}

Metode penulisan yang digunakan ialah dengan metode deskriptif. Dimana dilakukan dengan teknik pengumpulan data atau informasi dengan melakukan analisis, eksplorasi, kajian bebas (literatur review) yang relevan yang berfokus pada tema yaitu bagimana upaya kesehatan keselamatan kerja dan pencegahan penyakit akibat kerja pada perawat. Adapun sumber yang digunakan dalam penulisan ini menggunakan sumber dari jurnal dengan memasukkan kata kunci upaya kesehatan keselamatan kerja dan pencegahan penyakit akibat kerja pada perawat.

\section{Hasil}

Pemicu penyakit karena kerja Bahaya potensial yang dapat menyebabkan penyakit akibat kerja (PAK) yang terjadi di rumah sakit, umumnya berkaitan dengan :

1.faktor biologi (kuman patogen yang umumnya berasal dari pasien, seperti bakteri, viral diseases, parasitic diseases dan sebagainya)

2. faktor kimia (pemaparan dalam dosis kecil namun terus menerus seperti antiseptik pada kulit, gas anestesi pada hati, debu yang bisa menyebabkan pneumoconioses dan sebagaimya, uap

serta gas beracun yang bisa mengakibatkan keracunan)

3.faktor ergonomi (Tempat kerja, alat kerja yang tidak ergonomis, langkah kerja yang salah, konstruksi yang salah hingga bisa mempunyai dampak kelelahan pada tubuh, seperti tata cara duduk, tata cara mengankat pasien)

4.faktor fisik dalam dosis kecil yang terus menerus (suhu udara panas, listrik tegangan tinggi, dan radiasi) 
5.faktor psikologis ( hubungan kerja antar karyawan atau atasan serta tata cara kerja di kamar bedah, dibagian penerimaan pasien, di unit gawat darurat dan ruang perawatan)

\section{Pembahasan}

Penyakit Akibat Kerja adalah penyakit yang disebabkan oleh pekerjaan dan lingkungan kerja. Faktor risiko PAK antara lain: Golongan fisik, kimiawi, biologis atau psikososial di tempat kerja. Faktor tersebut di dalam lingkungan kerja merupakan penyebab yang pokok dan menentukan terjadinya penyakit akibat kerja. Faktor lain seperti kerentanan individual juga berperan dalam perkembangan penyakit di antara pekerja yang terpajam

\section{Golongan fisik}

a. Kebisingan dapat mengakibatkan gangguan pada pendengaran sampai dengan Non-induced hearing loss

b. Radiasi (sinar radio aktif) dapat mengakibatkan kelainan darah dan kulit

c. Suhu udara yang tinggi dapat mengakibatkan heat stroke, heat cramps, atau hyperpyrexia. Sedangkan suhu udara yang rendah dapat mengakibatkan frostbite, trenchfoot atau hypothermia.

d. Tekanan udara yang tinggi dapat mengakibatkan caison disease

e. Pencahayaan yang tidak cukup dapat mengakibatkan kelelahan mata antara pekerja yang terpajam.

\section{Golongan kimia}

a. Debu dapat mengakibatkan pneumokoniosis

b. Uap dapat mengakibatkan metal fume fever, dermatitis dan keracunan

c. Gas dapat mengakibatkan keracunan $\mathrm{CO}$ dan $\mathrm{H} 2 \mathrm{~S}$

d. Larutan dapat mengakibatkan dermatitis

e. Insektisida dapat mengakibatkan keracunan

3. Golongan infeksi 

a. Anthrax
b. Brucell
c. HIV/AIDS
4. Golongan fisiologis

Dapat disebabkan oleh kesalahan kontruksi, mesin, sikap badan yang kurang baik, salah cara melakukan suatu pekerjaan yang dapat mengakibatkan kelelahan fisik bahkan lambat laun dapat menyebabkan perubahan fisik pada tubuh pekerja.

\section{Golongan mental}

Dapat disebabkan oleh hubungan kerja yang tidak baik atau keadaan pekerjaan yang monoton yang menyebabkan kebosanan.

Menurut Peraturan Menteri Tenaga Kerja dan Transmigrasi Nomor PER- 01/MEN/1981 dan Keputusan Presiden RI No 22/1993 terdapat 31 jenis penyakit akibat kerja yaitu sebagai berikut:1

1. Pneumokoniosis yang disebabkan oleh debu mineral pembentukan jaringan parut (silikosis, antrakosilikosis, asbestosis) dan silikotuberkulosis yang silikosisnya merupakan faktor utama penyebab cacat atau kematian.

2. Penyakit paru dan saluran pernafasan (bronkopulmoner) yang disebabkan oleh debu logam keras.

3. Penyakit paru dan saluran pernafasan (bronkopulmoner) yang disebabkan oleh debu kapas, vlas, henep dan sisal (bissinosis).

4. Asma akibat kerja yang disebabkan oleh penyebab sensitisasi dan zat perangsang yang dikenal berada dalam proses pekerjaan.

5. Alveolitis allergika yang disebabkan oleh faktor dari luar sebagai akibat penghirupan debu organik

6. Penyakit yang disebabkan oleh berillium atau persenyawaannya yang beracun. 
7. Penyakit yang disebabkan oleh kadmium atau persenyawaannya yang beracun.

8. Penyakit yang disebabkan oleh fosfor atau persenyawaannya yang beracun.

9. Penyakit yang disebabkan oleh krom atau persenyawaannya yang beracun.

10. Penyakit yang disebabkan oleh mangan atau persenyawaannya yang beracun.

2. Golongan kimia

a. Debu dapat mengakibatkan pneumokoniosis

b. Uap dapat mengakibatkan metal fume fever, dermatitis dan

keracunan

c. Gas dapat mengakibatkan keracunan $\mathrm{CO}$ dan $\mathrm{H} 2 \mathrm{~S}$

d. Larutan dapat mengakibatkan dermatitis

e. Insektisida dapat mengakibatkan keracunan

3. Golongan infeksi

a. Anthrax

b. Brucell

c. HIV/AIDS

4. Golongan fisiologis

Dapat disebabkan oleh kesalahan kontruksi, mesin, sikap badan yang kurang baik, salah cara melakukan suatu pekerjaan yang dapat mengakibatkan kelelahan fisik bahkan lambat laun dapat menyebabkan perubahan fisik pada tubuh pekerja.

\section{Diagnosis Penyakit Akibat Kerja}


Secara teknis penegakan diagnosis dilakukan dengan cara berikut ini: 1. Tentukan diagnosis klinis dengan anamnesis yang baik, pemeriksaan fisik diagnostik dan pemeriksaan penunjang.

2. Tentukan pajanan terhadap faktor risiko dengan melakukan anamnesis mengenai riwayat pekerjaan secara cermat dan teliti yang mencakup:

Kapan pertama kali bekerja, sudah berapa lama bekerja, apa yang dikerjakan, bahan yang digunakan, informasi bahan yang digunakan (Material Safety Data Sheet/MSDS), bahan yang diproduksi, jenis bahaya yang ada, jumlah pajanan, kapan mulai timbul gejala, kejadian sama pada pekerja lain, pemakaian alat pelindung diri, cara melakukan pekerjan, pekerjaan lain yang dilakukan, kegemaran (hobi) dan kebiasaan lain (merokok, alkohol)

Membandingkan gejala penyakit sewaktu bekerja dan dalam keadaan tidak bekerja

a. Pada saat bekerja maka gejala timbul atau menjadi lebih berat, tetapi pada saat tidak bekerja atau istirahat maka gejala berkurang atau hilang

b. Perhatikan juga kemungkinan pemajanan di luar tempat kerja

c. Informasi tentang ini dapat ditanyakan dalam anamnesis atau dari data penyakit di perusahaan

\section{Pencegahan}

Berikut ini adalah penerapan konsep lima tingkatan pencegahan penyakit (five level of prevention disease) pada penyakit akibat kerja, yakni:2,4

a. Peningkatan kesehatan (health promotion). Misalnya: penyuluhan kesehatan dan keselamatan kerja (K3) pendidikan kesehatan, meningkatkan gizi yang baik, pengembangan kepribadian, perusahaan yang sehat dan memadai, rekreasi, lingkungan kerja yang memadai, penyuluhan perkawinan dan pendidikan seksual, konsultasi tentang keturunan dan pemeriksaan kesehatan periodik.

b. Perlindungan khusus (specific protection). Misalnya: imunisasi, hygiene perorangan, sanitasi lingkungan, serta proteksi terhadap bahaya dan kecelakaan kerja dengan menggunakan alat 
pelindung diri (APD) seperti helm, kacamata kerja, masker, penutup telinga (ear muff dan ear plug) baju tahan panas, sarung tangan, dan sebagainya.

c. Diagnosis (deteksi) dini dan pengobatan segera serta pembatasan titik-titik lemah untuk mencegah terjadinya komplikasi.

d. Membatasi kemungkinan cacat (disability limitation). Misalnya: memeriksa dan mengobati tenaga kerja secara komprehensif, mengobati tenaga kerja secara sempurna dan pendidikan kesehatan.

e. Pemulihan kesehatan (rehabilitation). Misalnya: rehabilitasi dan mempekerjakan kemali para pekerja yang menderita cacat. Sedapat mungkin perusahaan mencoba menempatkan keryawankaryawan cacat di jabatan yang sesuai.

Upaya yang dapat dilakukan oleh perusahaan untuk mencegah PAK adalah sebagai berikut:

1. Menyingkirkan atau mengurangi risiko pada sumbernya, misalnya menggantikan bahan kimia yang berbahaya dengan bahan yang tidak berbahaya.

2. Mengurangi risiko dengan pengaturan mesin atau menggunakan APD.

3. Menetapkan prosedur kerja secara aman untuk mengurangi risiko lebih lanjut.

4. Menyediakan, memakai APD

\section{Penutup}

Kehidupan manusia idak pernah terlepas dari pekerjaan, apapun jenis pekerjaan selalu dilakukan dalam rangka memenuhi kebutuhan sehari-hari, mulai dari pekerjaan berisiko rendah hingga berisiko tinggi. Disamping itu pemahaman dan penerapan keselamatan dan kesehatan kerja (K3) masih kurang di perhatikan oleh pekerja formal maupun informal. Pada hal factor K3 sangat penting dan harus diperhatikan oleh pekerja dan hal ini menjadi tanggung jawab bersama, perlu adanya kerja sama antara pemerintah, perusahaan dan pekerja agar terhindar dari Kecelakaan Akibat Kerja (KAK) dan Penyakit Akibat Kerja Keselamatan dan Kesehatan Kerja merupakan upaya perlindungan tenaga kerja dari bahaya, penyakit dan kecelakaan akibat kerja maupun lingkungan kerja. Penegakan diagnosis spesifik dan sistem pelaporan penyakit akibat kerja 
penting dilakukan agar dapat mengurangi dan atau bebas dari kecelakaan kerja dan penyakit akibat kerja yang pada akhirnya dapat meningkatkan efisiensi dan produktivitas (PAK).

\section{Referensi}

Adisasmito, W., 2012. Audit Lingkungan Rumah Sakit. Jakarta : Rajawali Press

Grahanintyas, D., Wignjosoebroto, S. dan Latiffanti, E. Analisa Keselamatan dan Kesehatan Kerja (K3) dalam Meningkatkan Produktivitas Kerja (Studi Kasus: Pabrik Teh Wonosari PTPN XII). Jurnal Teknik Pomits. 2012; Volume 1(1): 1-6.

Hanifa, N D., Titik R., \& Yuli S. (2017). Hubungan Pengetahuan dengan Upaya Penerapan K3 pada Perawat. 1(1), 144-149.

Hasugian, A R. (2017). Perilaku Pencegahan Penyakit Akibat Kerja Litbangke, 27(2), 111-124. Kerja Indonesia di Zambia: Anali

Kun Dwi Apriliawati, Ekawati, B. K. (2017). Efektivitas Pelaksanaan Manajemen Organisasi Keselamatan dan Kesehatan Kerja Rumah Sakit (K3RS) Di Rumah Sakit X Semarang.

Rudiyanto. Publik Berhak Tahu Kecelakaan Kerja. Katiga. 54(8). 2014:14-17.

Salawati, L. (2015). Penyakit Akibat Kerja dan Pencegahan. Jurnal Kedokteran Syiah Kuala 15(2), 91-95.

Simamora, R. H. (2020). Pelatihan Komunikasi Efektif untuk Meningkatkan Efikasi diri Perawat dalam Pelaksanaan Identifikasi Pasien. JURNAL ILMIAH KESEHATAN MASYARAKAT: Media Komunikasi Komunitas Kesehatan Masyarakat, 12(1), 49-54.

Simamora, R. H. (2011). ROLE CONFLICT OF NURSE RELATIONSHIP WITH PERFORMANCE IN THE EMERGENCY UNIT OF HOSPITALS RSD DR. SOEBANDI JEMBER. The Malaysian Journal of Nursing, 3(2), 23-32.

Sucipto, D. C. (2014).Keselamatan Dan Kesehatan Kerja. Yogyakarta: Gosyeng Publisher. 
Sunandar, Ibrahim. H, Damayanti,S.D, A.(2017). Gambaran Penerapan Standart Keselamatan dan Kesehatan Kerja Rumah Sakit Umum Daerah Haji Makassar, Public Health Science Journal, 9(2), 160-173. Universitas Islam Negeri Alauddin Makassar.

Suaeb A. Keselamatan dan Kesehatan Kerja. Jakarta: Universitas Gunadarma; 2013 